\title{
Neobvyklý nález zlatohlávka v rakvi biskupa Františka Petra Krejčího (1796-1870)
}

\author{
Dominik Vondráček ${ }^{1}$ \& Jan Cvrček ${ }^{2}$
}

\footnotetext{
${ }^{1}$ Entomologické oddělení, Národní muzeum, Cirkusová 1740, 19300 Praha 9; dominik.vondracek@nm.cz ${ }^{2}$ Antropologické oddělení, Národní muzeum, Cirkusová 1740, 19300 Praha 9; jan.cvrcek@nm.cz
}

Vondráček D. \& Cvrček J., 2020: Neobvyklý nález zlatohlávka v rakvi biskupa Františka Petra Krejčího (1796-1870). - Journal of the National Museum (Prague), Natural History Series 189: 167-172.

K exhumaci lidských ostatků se $\mathrm{v}$ antropologii přistupuje jen vzácně, zpravidla jen z velmi závažných důvodů. $\mathrm{Z}$ etického hlediska by takové jednání nemělo být samoúčelné. Mohou si ji vyžádat orgány činné v trestním řízení, může být vyvolána zrušením hrobového místa či dokonce sanací hřbitova nebo jeho části, snahou rodiny o převoz ostatků blízkého člověka na jiné místo nebo jen o jejich pietní uspořádání. $\mathrm{V}$ neposlední řadě tu je celospolečenská snaha o zachování hrobů významných osobností kulturního a politického života, a proto jsou často pod dohledem úřadů a památkářů. Pro biologické i historické obory to však současně bývá mimořádná př́ležitost $\mathrm{k}$ výzkumu, který není možné jiným způsobem realizovat, at' už jde o porovnání historických záznamů o okolnostech pohřbu s nálezovou situací a konkrétními artefakty, srovnání demografických ukazatelů kostry a zdravotního stavu s doloženými biografickými údaji, a textilní, zoologické, entomologické nebo botanické analýzy apod.

Nevyhovující stav hrobky i rakve stál také za exhumací ostatků biskupa Františka Petra Krejčího (obr. 1). Narodil se 27. června 1796 v Březině u Mnichova Hradiště. Teologii vystudoval v Litoměřicích a 24. srpna 1819 byl vy-

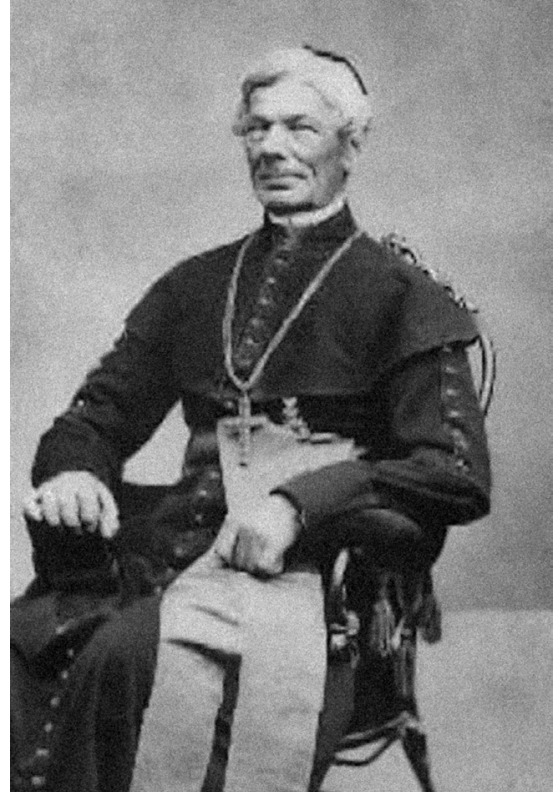

Obr. 1. Portrét biskupa Františka Petra Krejčího (1796-1870), fotoateliér M. L. Winter v Praze, 60. léta 19. století. Zdroj: Wikipedia (úprava J. Štěpán). svěcen na kněze. Poté byl kaplanem v Turnově, kde se v roce 1828 stal děkanem. V roce 1837 byl jmenován pražským kanovníkem, a roku 1854 generálním vikářem. V roce 1858 se stal světícím biskupem pražským a titulárním bis- 
kupem oropským (Itálie). V ř́ínu 1863 byl jmenován děkanem pražské metropolitní kapituly u sv. Víta. V 60. letech 19. století byl také poslancem Českého zemského sněmu, a po celou svou církevní kariéru významně podporoval turnovské studenty a tamní ochotnické divadlo. Zemřel 4. července 1870 v Praze stižen mrtvicí. Nejprve se připravoval jeho pohřeb v Praze, nakonec byl ale převezen do Turnova, kde 8. července spočinul v masivní kovové rakvi v hrobce pod křížem, který sám financoval (obr. 2). Na jaře 2020 komisionální prohlídka hrobky prokázala její nadále nevyhovující technický stav a zcela rozpadlé dno jeho rakve, přičemž jeho ostatky se již z části nacházely mimo ni. Proto bylo rozhodnuto o jejich exhumaci a dokumentaci ostatků pod vedením archeologů z turnovského Muzea Českého ráje a Antropologického oddělení Národního muzea. Na zhodnocení entomologických nálezů se podílelo Entomologické oddělení Národního muzea.

U kosterních ostatků $\mathrm{v}$ rakvích se totiž běžně nalézají zbytky živočichů, především pak hmyzu, kteří se na mrtvém těle přiživovali. Jde o roz-

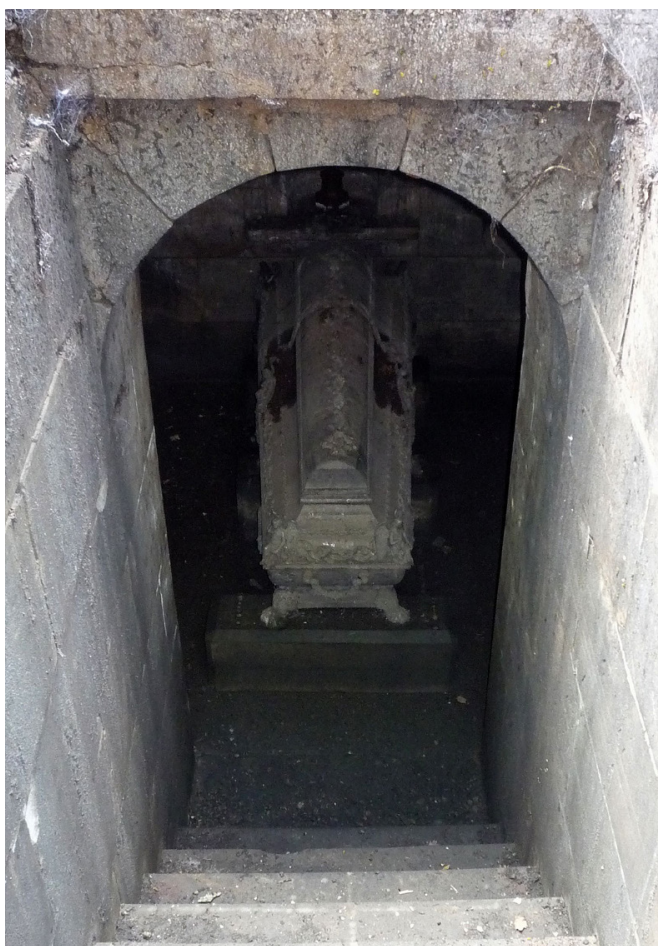

Obr. 2. Pohled do hrobky biskupa Františka Petra Krejčího (1796-1870) před exhumací, Mariánský hřbitov v Turnově. Foto: J. Cvrček. kladače, kteří takto likvidují uhynulé organismy, a to včetně lidí, jejichž ostatky tito tzv. saprofágové postupně zkonzumují a zbydou jen holé kosti. Běžně tak u volně loženého těla podléhajícímu rozkladu najdeme široké spektrum much, jejichž dospělci se živí olizováním měkkých tkání a zároveň samice kladou na kadáver vajíčka. Vylíhlé larvy pak často ve velmi hojném počtu požírají svalovinu i vnitřní orgány. Jde především o zástupce čeledí bzučivkovití (Calliphoridae) a masařkovití (Sarcophagidae). Dále však můžeme narazit i na zástupce hrbilkovitých (Phoridae), lanýžkovitých (Heleomyzidae), sýrohlodkovitých (Piophilidae) či mrvnavkovitých (Sphaeroceridae). Objevují se i mrchožraví brouci, jako jsou například mrchožrouti a hrobaříci (Silphidae). Chlupy, vlasy, nehty či drobné zbytky svalové tkáně na kostech zvládnou zpracovat brouci čeledi kožojedovití (Dermestidae) a hlodáčovití (Trogidae). Poslední zmíněná skupina se př́mo specializuje na keratinové zbytky. Výjimečně lze pozorovat na mrtvolách např́íklad slimáky, chvostoskoky, případně i housenky některých druhů molovitých a zavíječovitých motýlů. Na toto široké spektrum organismů je navázána celá řada predátorů, kteří naopak konzumují tyto rozkladače, at' už dospělce, jejich vajíčka či larvy. Jde o různé druhy brouků z čeledí mršníkovití (Histeridae), drabčíkovití (Staphylinidae), potemníkovití (Tenebrionidae) nebo střevlíkovití (Carabidae) a pestrokrovečníkovití (Cleridae). Na mršinách predují i různí pavouci a roztoči. Na kadáver mohou naletovat dále vosy, at' už z důvodu přiživení se na mrtvole samotné, tak i predace zmíněných rozkladačů a jejich predátorů.

V rakvích se běžně nalézají zbytky zmíněných živočichů. Jde především o prázdné kukly, tzv. pupária dvoukř́́dlého hmyzu, která také byla v hojné míre při exhumaci biskupa nalezena. Bylo tedy překvapením, když byl v ostatcích nalezen dospělý zástupce čeledi vrubounovití (Scarabaeidae). Přesněji šlo o zlatohlávka sensu stricto (podčeled' Cetoniinae, tribus 
Cetoniini). Dospělí zlatohlávci jsou totiž ve většině případů býložraví. Živí se pylem a nektarem z květů, samotnými květy, čerstvými lístky nebo přezrálým ovocem či vytékající mízou listnáčů. Existují však výjimky. Někteří zlatohlávkovití brouci mohou být draví. Jde o zástupce subtribu Cremastocheilina. U těchto zlatohlávků byla pozorovaná predace mravenců a termitů, nebo larev a kukel blanokřídlého hmyzu či kř́sů. U rodu Spilophorus bylo pozorováno pojídání hnízdního materiálu a exkrementů pocházejících od afrických pěvců, kde se i tito brouci vyskytují. U druhu Oplostomus fuligineus bylo prokázáno i vyžírání zásob ve včelích úlech (včetně již zmíněného pojídání larev a kukel včel). Všichni tito zlatohlávci však nežijí v ČR, ani v Evropě. Nejblíže jsou k nalezení v severovýchodní Africe a jejich centrum diverzity leží v Africe a v Asii. Larvy zlatohlávků se živí rozkládající se rostlinnou hmotou (trouch, listová hrabanka, tlející kořínky bylin, kompost, hnůj atd.), popřípadě inklinují ke koprofagii. Vzácně jsou dravé a požírají jiné bezobratlé. Opět tedy není znám případ mrchožravé larvy zlatohlávka.

Námi zkoumaný jedinec byl v ostatcích nalezen mezi pravou lopatkou a přilehlými žebry (obr. 3), které zůstaly částečně spojené v důsledku přítomnosti mumifikovaných měkkých tkání. Vzhledem k silnému znečištění zvířete (obr. 4) nebylo možné ihned říct, zdali se jedná o druh žijící v ČR, či zvíře, které žije v okolních částech Evropy, nebo někde jinde ve světě. Na základě celkového vzhledu jsme však mohli okamžitě vyloučit dravé, či saprofágní zástupce skupiny Cremastocheilina, jejichž morfologie je značně odlišná a výrazně přizpůsobená zmíněným způsobům života.

I tak ale vyvstalo několik teorií, jak se tam zvíře mohlo dostat. Jde o domácí druh, který tam zalétl před zavřením rakve a byl zaživa pohřben s již mrtvým biskupem, nebo jde o cizokrajné zvíře? Jak by se tam pak mohlo dostat, když rakev neopustila území Čech? Nebo byl dokonce, pakliže uvážíme možnost cizokrajného původu, do rakve vložen úmyslně? Jak by se pak ale $\mathrm{v}$ takovém př́padě dostal pod několik vrstev jinak kompletně zachovalého oděvu?

$\mathrm{K}$ zodpovězení těchto otázek mohlo dojít jen očištěním exempláře a jeho následnou determinací. Pro určení zlatohlávků do druhu bývá často stěžejní i samotné zbarvení jedince, povrchová struktura krovek a dalších

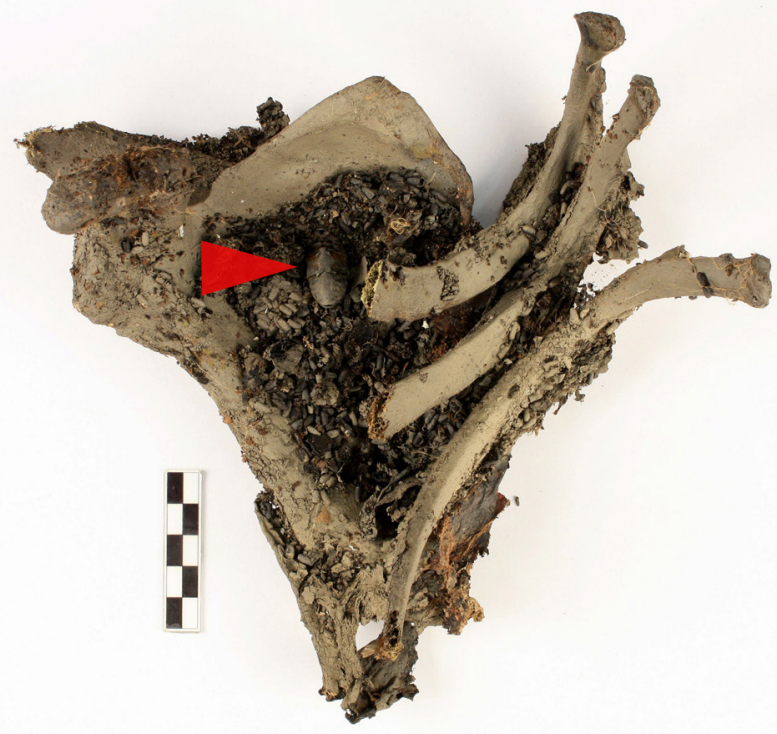

Obr. 3. Pravá lopatka a přilehlá žebra, stav po vyzvednutí z rakve s nálezem zlatohlávka (šipka) a velkým množstvím pupárií. Foto: J. Cvrček.

částí těla, nebo samčí genitál.

Jedinec byl tedy podroben

kombinaci chemického a mechanického čištění. Byl ponořen do lékařského benzínu, aby se rozpustil nános nečistot a následně byl dočištěn ještě za pomoci pinzety a štětce. Nečistoty však byly elementem, který části jeho těla držel pohromadě, a tak se po očištění rozpadl na několik desítek částí, které bylo nutné opětovně slepit a brouka tak dostat do výsledné vypreparované podoby. Během preparace bylo zjištěno, že jde o samici. Samčí genitál, který je 

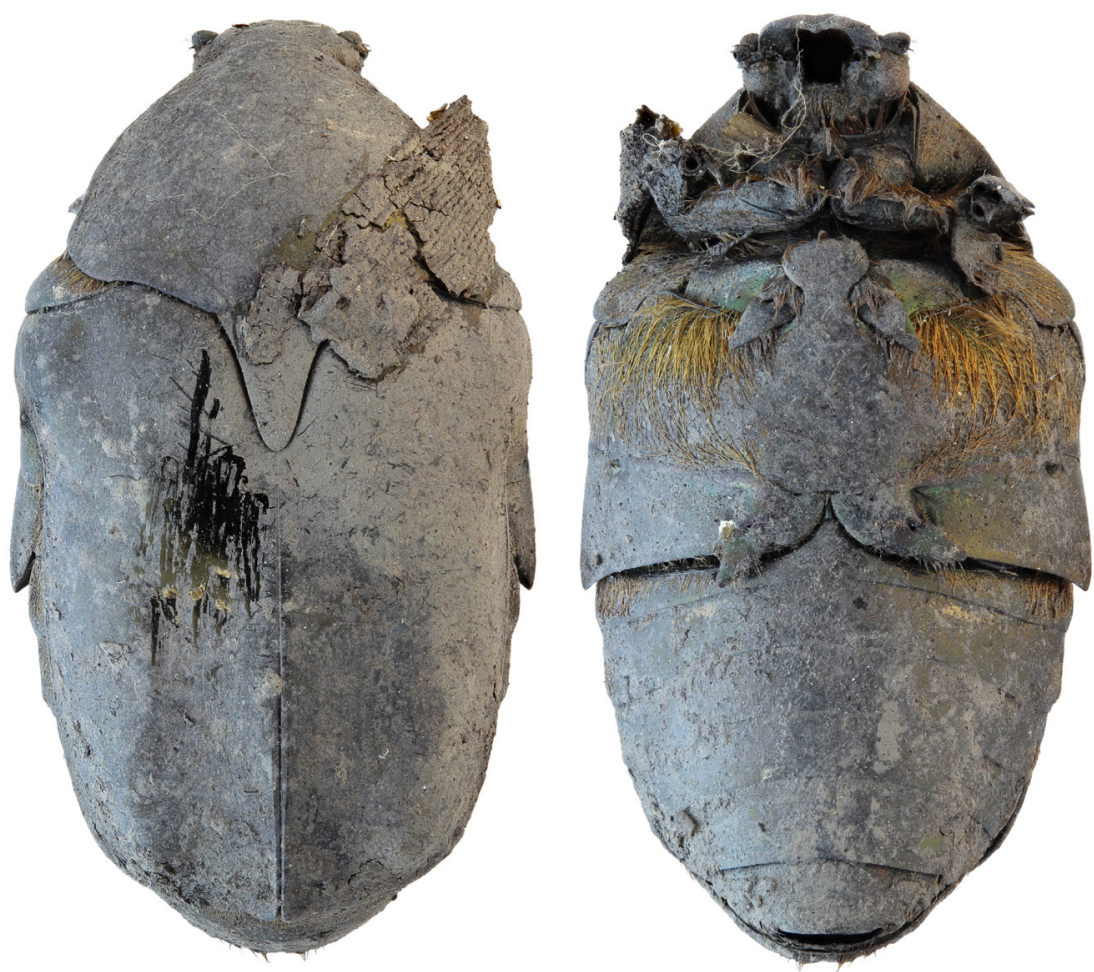

Obr. 4. Dorsální (vlevo) a ventrální (vpravo) pohled na celkový habitus nalezeného zlatohlávka s viditelným nánosem nečistot. $Z$ dorsální strany je na levé krovce patrné částečné mechanické odstranění nečistot pinzetou. Foto: D. Vondráček.

silně sklerotizovaný a nepodléhá zkáze, stejně jako samotné tělo, nebyl v zadečku přítomen. Naopak se tam nacházelo přibližně 15 kuličkovitých útvarů, které odpovídali velikostně i počtem vajíčkům takto velkého zlatohlávka. Šlo tedy o samici, která již měla připravená vajíčka k oplodnění, nebo k samotnému kladení.

Po očištění bylo zjištěno, že se jedná o zlatohlávka mramorovaného Protaetia (Liocola) marmorata (Fabricius, 1792), (obr. 5). V rámci české a evropské fauny je tento druh nezaměnitelný díky kombinaci velikosti, několika morfologických znaků a specifického tmavého zbarvení. Samice zlatohlávka mramorovaného lze zaměnit pouze se samicemi druhu Protaetia (Oreopotosia) thibetana (Kraatz, 1889), což je ale poměrně vzácný endemit centrální Číny a dodnes se ve sbírkách vyskytuje pouze ojediněle. Zlatohlávek mramorovaný je běžným evropských druhem, který se vyskytuje i ve vyšších nadmořských výškách. Distribuční areál tohoto brouka se rozkládá v podstatě po celé Evropě a zasahuje dále na východ do oblastí Sibiře, Kazachstánu a Mongolska. Dorůstá velikosti 18-26 mm, z vrchu je bronzově až hnědavě zbarvený, ze spodu taktéž tmavý, ale více do zelena. Na krovkách a štítě má výrazné bílé skvrny. Ty se objevují i na spodní straně na zadečkových článcích. Dospělci jsou aktivní od května do konce léta, navštěvují především mízotoky, popřípadě květy bezů a svíd. Žijí poměrně skrytým způsobem života a těžko se hledají, i když jsou na lokalitách v hojných počtech. Monitoring se tak provádí hlavně díky ovocným pastím, které je přilákají. Ke svému vývoji potřebují dutiny ve starých listnáčích. Jde především o duby, vrby, lípy, ale i ovocné 
stromy. Larvy se živí trouchnivějícím dřevem. V dutině se poté i zakuklí ve vytvořeném kokonu z okolního materiálu. Vylíhnutí dospělci přečkávají v kokonech zimu a vylézají ven až na jaře dalšího roku.

Vzhledem ke všem dostupným informacím lze s největší pravděpodobností tvrdit, že jde o jedince, který nevědomky vletěl do rakve biskupa před jejím uzavřením, kde se následně snažil dostat ven, ale nakonec zabloudil pod oblečení zemřelého, kde uhynul a z důvodu rozkladu těla se propadl mezi kosti pravého pletence horní končetiny a přilehlá žebra, a tam zůstal po 150 let uchován. Vzhledem k umístění kovové rakve a masivního záklopu celé hrobky je v podstatě nemožné, aby se zlatohlávek dostal do rakve později. Křehkost samotného jedince a následný rozpad po očištění jen potvrzuje výrazné stáří uhynulého brouka. Možnost nakladení vajíčka dospělým zlatohlávkem a následné přežití larvy, která by dokon-
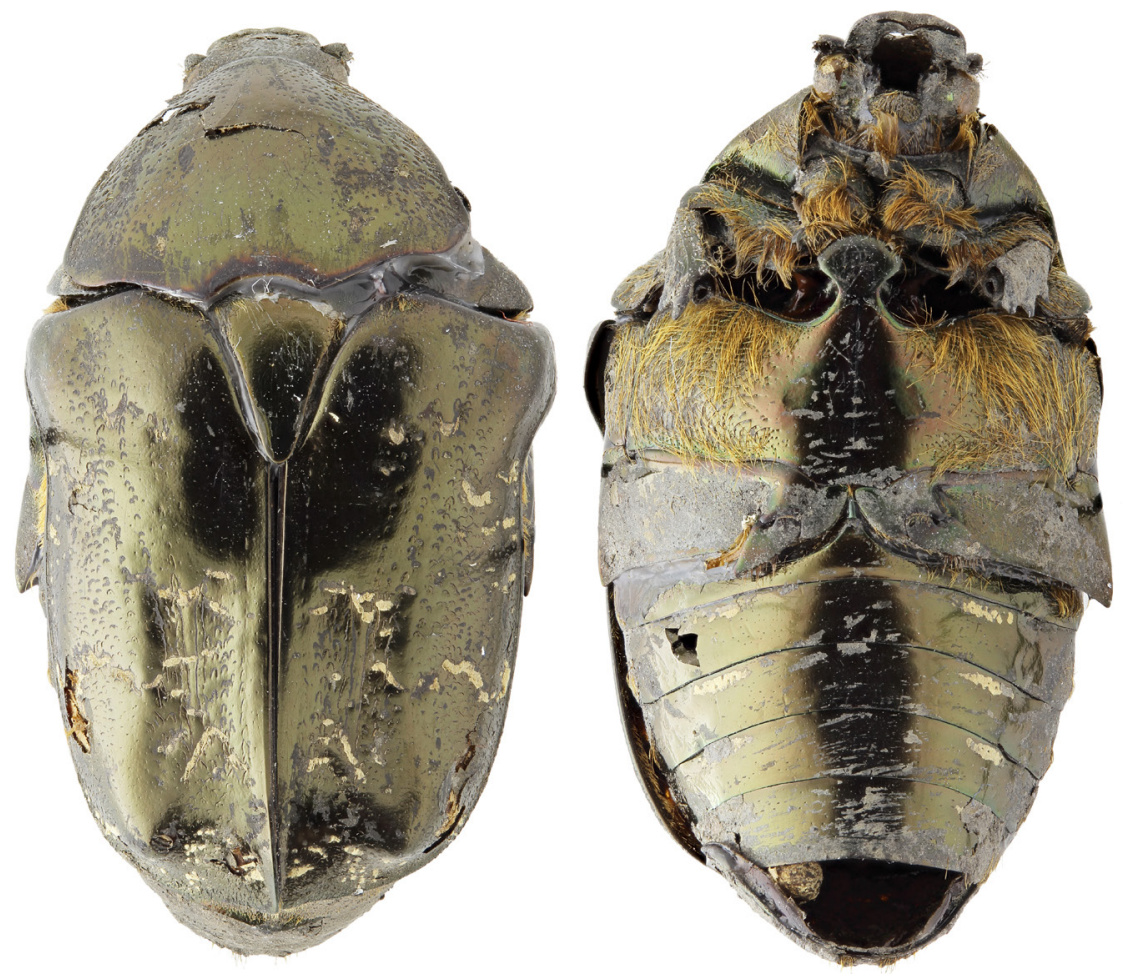

Obr. 5. Dorsální (vlevo) a ventrální (vpravo) pohled na celkový habitus očištěného a slepeného jedince, který byl determinován jako Protaetia (Liocola) marmorata (Fabricius, 1792), tedy zlatohlávek mramorovaný. Foto: D. Vondráček.

čila svůj vývoj v kovové rakvi, můžeme taktéž vyloučit. Larva by v takovém prostředí vývoj zcela jistě dokončit nemohla. Vypreparovaný zlatohlávek byl opatřen netradičním lokalitním a determinačním štítkem (obr. 6), tak aby bylo zřejmé, o jaký druh nálezu se jedná. Následně byl zařazen do systematické sbírky depozitářru entomologického oddělení mezi další jedince tohoto druhu. 
CZECH REP.: Turnov cemetery area (Mariánský hřbitov) inside of a tomb $50.5863817 \mathrm{~N} 15.1603431 \mathrm{E}$ 30.vi.2020, Cvrček, Kuželka, Prostředník \& Veleminský lgt.
Dead specimen laying inside of human remains in a metal coffin. Remains belonged to František Petr Krejči (1796-1870). Specimen was there probably for 150 years.
Protaetia (Liocola) marmorata

(Fabricius, 1792)

?

D. Vondráček det. 2020

Obr. 6. Lokalitní a determinační štítky, kterými byl zlatohlávek opatřen a následně uložen do sbírky Národního muzea. Foto: D. Vondráček.

\section{Poděkování}

Autoři děkují Janu Prostředníkovi (Muzeum Českého ráje v Turnově) a kolegům Vítězslavu Kuželkovi a Petru Velemínskému (Antropologické oddělení, Národní muzeum) za přizvání k výzkumu ostatků biskupa Františka Petra Krejčího. Poděkování patří i kolegovi Stanislavu Jáklovi za radu ohledně potenciální záměny zlatohlávka mramorovaného s jinými druhy.

Předkládaná práce byla finančně podpořena Ministerstvem kultury České republiky (DKRVO 2019-2023/5.I.b, a DKRVO 2019-2023/7.I.b, Národní muzeum, 00023272).

\section{Internetové zdroje}

Wikipedie - portrét biskupa Františka Petra Krejčího:

https://cs.wikipedia.org/wiki/Franti\%C5\%A1ek_Petr_Krej\%C4\%8D\%C3\%AD\#/media/Soubor:Franti\%C5\%A1ek_Petr_Krej\%C4\%8D\%C3\%AD_(1796-1870).jpeg

\section{Summary}

\section{Unusual find of a flower chafer in the coffin of František Petr Krejčí (1796-1870) \\ Dominik Vondráček \& Jan Cvrček}

Exhumation of human remains during miscellaneous research is a common procedure used by anthropologists, including those from National Museum in Prague. Insect remnants, especially puparia of Diptera, are regularly found in cadavers extracted from coffins or tombs, but an unusual find was made during the examination of the remains of bishop František Petr Krejčí (1796-1870), buried in Turnov (Czech Republic). In his coffin, a flower chafer was found under several layers of his preserved clothes, between the right scapula and ribs. The specimen was cleaned and later determine to be a Marbled Rose Chafer (Proteatia marmorata), which is an ordinary species not only in the Czech Republic, but all over Europe as well. Based on the bionomy of this species and bishop's biography, we concluded that the specimen got inside just before closing of the coffin and died there. Only one other species resembles the Marbled Rose Chafer, but it is endemic to areas in central China. That is Protaetia thibetana, which is still quite rare and very uncommon in entomological collections. 